\title{
Presence of Amblyomma cajennense in Wild Giant Armadillos (Priodontes maximus) of the Pantanal Matogrossense, Brazil
}

Author(s): Flávia Regina Miranda, Rodrigo Hidalgo Friciello Teixeira, Gilberto Salles Gazêta, Nicolau Maués Serra-Freire and Marinete Amorim

Source: Edentata, 11(1):73-75.

Published By: IUCN/SSC Anteater, Sloth and Armadillo Specialist Group

https://doi.org/10.1896/020.011.0113

URL: http://www.bioone.org/doi/full/10.1896/020.011.0113

BioOne (www.bioone.org) is a nonprofit, online aggregation of core research in the biological, ecological, and environmental sciences. BioOne provides a sustainable online platform for over 170 journals and books published by nonprofit societies, associations, museums, institutions, and presses.

Your use of this PDF, the BioOne Web site, and all posted and associated content indicates your acceptance of BioOne's Terms of Use, available at www.bioone.org/page/terms of use.

Usage of BioOne content is strictly limited to personal, educational, and non-commercial use.

Commercial inquiries or rights and permissions requests should be directed to the individual publisher as copyright holder. 


\section{Presence of Amblyomma cajennense in Wild Giant Armadillos (Priodontes maximus) of the Pantanal Matogrossense, Brazil}

\author{
Flávia Regina Miranda \\ Rodrigo Hidalgo Friciello Teixeira \\ Gilberto Salles Gazêta \\ Nicolau Maués Serra-Freire \\ Marinete Amorim
}

\begin{abstract}
The giant armadillo (Priodontes maximus) is the largest extant representative of the order Cingulata. Information on the parasites and diseases affecting this species is scarce. Four female and one male ticks were collected from two wild-caught, adult giant armadillos from the northern Pantanal, Mato Grosso, Brazil. All of them were identified as Amblyomma cajennense. This is the first report of $A$. cajennense in giant armadillos. Considering the low host specificity of this ixodid tick that may act as vector of pathogens, and the sustained encroachment of domestic animals into wildlife habitat, the risk of disease transmission from cattle to this threatened armadillo should be evaluated.
\end{abstract}

Keywords: Ticks, Ixodidae, Xenarthra, Cingulata

The giant armadillo (Priodontes maximus) is the largest extant representative of the order Cingulata. It is currently listed as Vulnerable by the IUCN Red List of Threatened Species (Superina et al., 2009). It occurs east of the Andes from Venezuela, Colombia, and the Guyanas to Paraguay, Argentina, and Brazil (Wetzel, 1982). The giant armadillo may occupy different habitats, from low and highland forests to lands covered with thorny shrubs and cerrado, although open areas are its favorite habitat (Anacleto, 1997). Information on the parasites and diseases affecting this species is scarce (Superina, 2000).

Systematic collection of parasites in wild animals can provide important information for the management of captive and free-ranging populations. The Ixodidae family is composed of 14 genera and approximately 670 species of hard ticks (Anderson, 2002). They have a dorsal shield that covers the entire idiosome in males, but only the anterior area in females and immature stages (larvae and nymphs). In addition, nymphs and adults have respiratory stigmas posterior to coxa IV (Anderson, 2002). Ixodid ticks are highly physiologically dependent of their hosts and can be vectors of a variety of pathogens that can cause disease in humans, domestic animals, and wildlife (Anderson and Magnarelli, 2008). Infectious agents may be transmitted transtadially (larva to nymph or nymph to adult) or transovarially, i.e., from generation to generation, as well as passed on to their hosts while obtaining a blood meal.

In Brazil, the first records of ticks of free-ranging mammals were provided by Aragão (1936), Fonseca and Aragão (1952, 1953), and Aragão and Fonseca (1961). Later reports include Serra Freire et al. (1996); Castro and Serra Freire (1996); Amorim et al. (1998); Evans et al. (2000); Guerra et al. (2000); Martins et al. (2004); and Miziara et al. (2008). Here, we report for the first time the presence of Ixododidae in wild giant armadillos (Priodontes maximus).

This study was conducted at the Reserva Particular de Patrimônio Natural do Serviço Social do Comércio, Pantanal (RPPN SESC Pantanal; $16^{\circ} 39^{\prime} \mathrm{S}, 56^{\circ} 15^{\prime} \mathrm{W}$ ), a Conservation Unit located in the northern portion of the Pantanal, state of Mato Grosso, Brazil. Two adult giant armadillos (Priodontes maximus), a male and a female, were captured by hand and chemically restrained with $10 \mathrm{mg} / \mathrm{kg}$ ketamine and $0.2 \mathrm{mg} / \mathrm{kg}$ midazolam. A clinical examination was performed and blood samples extracted. Ticks found attached to the armadillos were manually removed by twisting them around the longitudinal axis of their idiosome, preserved in $70 \%$ ethyl alcohol, and sent to the Ixodides Laboratory at the National Reference Center for Vectors of Rickettsias of the Oswaldo Cruz Foundation (FIOCRUZ) in Rio de Janeiro. The parasites were examined using a stereomicroscope and identified according to the dichotomic keys of Aragão and Fonseca (1961) and Barros-Battesti et al. (2006). Three female ticks were found on one armadillo, while the other was infested by a male and female tick. All of them were identified as Amblyomma cajennense (Fig. 1).

This is the first report of $A$. cajennense in P. maximus. Several ticks of this genus have been described in other armadillos. For instance, $A$. auricularium and $A$. pseudoconcolor have been observed on Dasypodidae (Guglielmone et al., 2003). A. brasiliense was found in Dasypus septemcinctus and D. novemcinctus (Evans et al., 2002), A. auricularium in D. novemcinctus (Amorim and Serra-Freire, 2000; Olegário et al., 2006), A. fuscum in D. septemcinctus (Aragão, 1936; Brum et al., 2003), and A. parvum in D. kappleri (Mullins et al., 2004). 


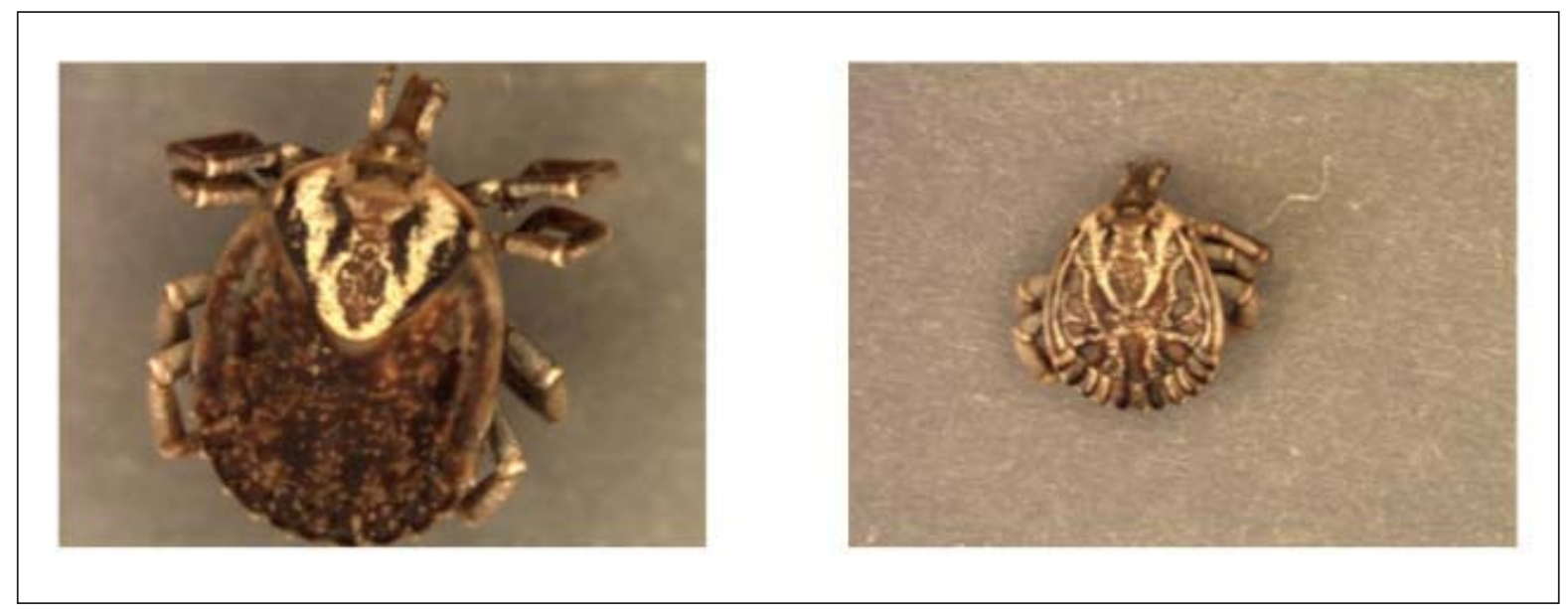

Figure 1. Amblyomma cajennense; left: adult female; right: adult male.

As a species with low host specificity, $A$. cajennense may transmit pathogens between wildlife species or between wild and domestic animals (Figueiredo et al., 1999). Considering the sustained encroachment of domestic animals into wildlife habitat, the risk of disease transmission from cattle to this threatened armadillo should be evaluated.

Acknowledgements: To the park rangers of the SESC Pantanal who helped us capturing the giant armadillos, FIOCRUZ for identification of the ticks, all those who directly or indirectly participated in this project, and the reviewers and editor for their helpful comments.

Flávia Miranda, Anteater Project and Wildlife Conservation Society - WCS, Alameda João de Barro 420, Mairiporã, São Paulo, CEP 07600-000, Brazil, e-mail: <fmiranda@wcs.org>; Rodrigo Hidalgo Teixeira, Zoológico Municipal "Quizinho de Barros", Sorocaba, São Paulo, CEP 18020-026, Brazil, e-mail: <rhftzoo@hotmail.com>; Marinete Amorim, Instituto Oswaldo Cruz (FIOCRUZ), Av. Brasil 4365, Manguinhos, Rio de Janeiro, CEP 21040-360, Brazil, e-mail: <mamorim@ioc.ficruz.br>; Gilberto Salles Gazêta, Instituto Oswaldo Cruz (FIOCRUZ), Av. Brasil 4365, Manguinhos, Rio de Janeiro, CEP 21040-360, Brazil; and Nicolau Maués Serra-Freire, Instituto Oswaldo Cruz (FIOCRUZ), Av. Brasil 4365, Manguinhos, Rio de Janeiro, CEP 21040-360, Brazil.

\section{References}

Amorim, M., Gazêta, G. S., Peralta, A. S. L., Teixeira, R. H. F. and Serra-Freire, N. M. 1998. Ixodofauna de quelônios do Brasil. Rev. Univ. Rural, Sér. Ci. Vida Seropédica, RJ, EDUR. 20: 31-35.
Amorim, M. and Serra-Freire, N. M. 2000. Morphological description of tick larval stage (Acari: Ixodidae). 7. Amblyomma auriculare (Conil, 1878). Entomol. Vect. 7: 297-310.

Anacleto, T. C. S. 1997. Dieta e utilização de hábitat do tatu-canastra (Priodontes maximus Kerr, 1792) numa área de cerrado do Brasil Central. Master's thesis, Universidade de Brasília, Brasília.

Anderson, J. F. 2002. The natural history of ticks. Med. Clin. North Am. 86: 205-218.

Aragão, H. 1936. Ixodidas brasileiros e de alguns paises limitrophes. Mem. Inst. Oswaldo Cruz 31: 759-843.

Anderson, J. F. and Magnarelli, L. A. 2008. Biology of ticks. Infect. Dis. Clin. North Am. 22: 195-215.

Aragão, H. B. and Fonseca, F. 1961. Notas de Ixodologia. VIII. Lista e chave para os representantes da fauna ixodológica brasileira. Mem. Inst. Oswado Cruz 59: 115-129.

Barros-Battesti, D. M., Arzua, M. and Bechara, G. H. 2006. Carrapatos de Importância Médico-Veterinária da Região Neotropical: Um Guia Ilustrado para Identificação de Espécies. Vox/ICTTD-3/ Butantan, São Paulo.

Brum, J. G. W., Valente, A. L. S., Albano, A. P., Coimbra, M. A. C. and Greque, G. G. 2003. Ixodidae de mamíferos silvestres atendidos no núcleo de reabilitação da fauna silvestre, UFPEL. Arq. Inst. Biol. 70: 211-212.

Castro, G. R. and Serra-Freire, N. M. 1996. Revisão da ixodofauna: I. Tamanduás (Tamandua sp.). Entomol. Vect. 3: 63-81.

Evans, D. E., Martins, J. R. and Guglielmone, A. A. 2000. A review of the ticks (Acari, Ixodida) of Brazil, their hosts and geographic distribution - 1. The state of Rio Grande do Sul, Southern Brazil. Mem. Inst. Oswaldo Cruz 95: 453-470. 
Figueiredo, L. T. M., Badra, S. J. , Pereira, L. E. and Szabó, M. P. J. 1999. Report on ticks collected in the Southeast and Mid-West regions of Brazil: analyzing the potential transmission of tickborne pathogens to man. Rev. Soc. Bras. Med. Trop. 32: 613-619.

Fonseca, F. and Aragão, H. B. 1952. Notas de Ixodologia. II Uma nova espécie e gênero Amblyomma e uma nova espécie do gênero Ixodes (Acari: Ixodidae). Mem. Inst. Oswaldo Cruz 50: 713-726.

Guerra, R. M. S. N. C., Silva, A. L. A. and SerraFreire, N. M. 2000. Amblyomma rotundatum Koch, 1844 (Acari: Ixodidae) in Kinosternon scorpioides L. (Chelonia: Kinosternidae) in Maranhão state, Brazil. Entomol. Vect. 7: 335-338.

Guglielmone, A. A., Estrada-Peña A., Luciani, C. A., Mangold. A. J. and Keirans, J. E. 2003. Hosts and distribution of Amblyomma auricularium (Conil 1878) and Amblyomma pseudoconcolor Aragão, 1908 (Acari: Ixodidae). Exp. Appl. Acarol. 29: 131-139.

Martins, J. R., Medri, I. M., Oliveira, C. M. and Guglielmone, A. A. 2004. Ocorrência de carrapatos em tamanduá-bandeira (Myrmecophaga tridactyla) e tamanduá-mirim (Tamandua tetradactyla) na região do Pantanal Sul Mato-Grossense, Brasil. Ciência Rural 34: 293-295.

Miziara, S. R., Paiva, F., Andreotti, R., Koller, W. W., Lopes, V. A., Pontes N. T. and Bitencourt, K. 2008. Occurrence of Ixodes loricatus Neumann, 1899 (Acari: Ixodidae) parasitizing Didelphis albiventris (Lund, 1841) (Didelphimorphia: Didelphidae) in Campo Grande, MS. Rev. Bras. Parasitol. Vet. 17: 158-160.

Mullins, M. C., Lazzarini, S. M., Picanço, M. C. L. and Serra-Freire, N. M. 2004. Amblyomma parvum a parasite of Dasypus kappleri in the state of Amazonas, Brazil. Rev. Cienc. Agrar. 42: 287-291.

Olegário, M. M. M., Szabó, M. P. J. and Santos, A. L. Q. 2006. Carrapatos em áreas do Cerrado brasileiro. Vet. Not. 12(2): 39.

Serra-Freire, N. M., Amorim, M., Gazêta, G. S., Guerim, L. and Desiderio, M. G. H. 1996. Ixodofauna de cervídeos no Brasil. Rev. Bras. Cienc. Vet. 3: 51-54.

Superina, M. 2000. Biologie und Haltung von Gürteltieren (Dasypodidae). Doctoral thesis, Institut für Zoo-, Heim- und Wildtiere, Universität Zürich, Zürich, Switzerland.

Superina, M., Abba, A. M., Porini, G. and Anacleto, T. C. S. 2009. Priodontes maximus. In: IUCN 2010. IUCN Red List of Threatened Species. Version 2010.2. <http://www.iucnredlist.org>. Downloaded on 06 August 2010.
Wetzel, R. M. 1982. Systematics, distribution, ecology and conservation of South American edentates. In: Mammalian Biology in South America, M. A. Mares and H. H. Genoways (eds.), pp. 345-375. Special Publication Series of the Pymatuning Laboratory of Ecology, University of Pittsburgh, Pittsburgh. 